Uniwersytet im. Adama Mickiewicza, Poznań

\title{
Prawa i obowiązki stron umowy licencyjnej dotyczącej wzorów przemysłowych w świetle regulacji krajowych i Unii Europejskiej
}

Wa wstępie należy przypomnieć, iż zgodnie z art. 102 ust. 1 ustawy 1 z dnia 30 czerwca 2000 r. prawo własności przemysłowej ${ }^{1}$, wzorem przemysłowym jest nowa i posiadająca indywidualny charakter postać wytworu lub jego części, nadana mu w szczególności przez cechy linii, konturów, kształtów, kolorystykę, strukturę lub materiał wytworu oraz przez jego ornamentację ${ }^{2}$. Przy czym - jak to definiuje ust. 2 tego przepisu - wytworem jest każdy przedmiot wytworzony w sposób przemysłowy lub rzemieślniczy, obejmujący w szczególności opakowanie, symbole graficzne oraz kroje pisma typograficznego, z wyłączeniem programów komputerowych. Za wytwór uważa się także: 1) przedmiot składający się z wielu wymienialnych części składowych umożliwiających jego rozłożenie i ponowne złożenie (tzw. wytwór złożony), 2) część składową jeżeli po jej włączeniu do wytworu złożonego pozostaje widoczna w trakcie jego zwykłego używania, przez które rozumie się każde używanie, z wyłączeniem konserwacji, obsługi lub naprawy, a wreszcie 3) część składową, jeżeli może być przedmiotem samodzielnego obrotu ${ }^{3}$.

W art. 103 ust. 1 ustawy zdefiniowano przesłankę nowości, a mianowicie wzór przemysłowy uważa się za nowy, jeżeli przed datą, według której oznacza się pierwszeństwo do uzyskania prawa z rejestracji, identyczny wzór nie został udostępniony publicznie przez stosowanie, wystawienie lub ujawnienie w inny sposób. Jednocześnie ust. 2 tego przepisu

1 Ustawa z dnia 30 czerwca 2000 r. Prawo własności przemysłowej, t.j.: Dz. U. 2003, Nr 119, poz. 1117 z późn. zm. - dalej zwana ustawą.

2 Por. szerzej E. Nowińska, Prawo własności przemysłowej. Wzory przemysłowe, znaki towarowe, oznaczenia geograficzne, t. II, Zakamycze 2005, s. 36 i n.

${ }^{3}$ Z kolei zgodnie z art. 102 ust. 4 ustawy, w przypadku wzoru stosowanego lub zawartego w części składowej wytworu złożonego, ocena nowości i indywidualnego charakteru dotyczy tylko jego widocznych cech. 
stanowi, iż wzór uważa się za identyczny z udostępnionym publicznie także wówczas, gdy różni się od niego jedynie nieistotnymi szczegółami. Przy czym wzoru nie uważa się za udostępniony publicznie, jeżeli nie mógł dotrzeć do wiadomości osób zajmujących się zawodowo dziedziną, której wzór dotyczy. Powyższe jednak nie wyłącza możliwości udzielenia prawa z rejestracji, jeżeli wzór przemysłowy: 1) został ujawniony osobie trzeciej, która w sposób wyraźny lub dorozumiany była zobowiązana do zachowania poufności, 2) został ujawniony w ciagu 12 miesięcy przed data, według której oznacza się pierwszeństwo do uzyskania prawa z rejestracji, jeżeli ujawnienie nastąpiło przez twórcę, jego następcę prawnego lub - za zgodą uprawnionego - przez osobę trzecią, a także jeżeli ujawnienie nastąpiło w wyniku nadużycia popełnionego wobec twórcy lub jego następcy prawnego.

Warto tu przytoczyć poglądy judykatury w tym zakresie. Otóż w wyroku Wojewódzkiego Sądu Administracyjnego w Warszawie z dnia 29 marca 2007 r. zaakcentowano, iż w świetle przepisów art. 102-104 ustawy z dnia 30 czerwca 2000 r. - Prawo własności przemysłowej, dopuszczalna jest rejestracja wzoru przemysłowego, który stanowi kombinację cech znanych już z wcześniejszych wzorów, jeżeli ogólne wrażenie, jakie wywiera ten wzór, różni się od wrażenia wywieranego przez porównywane wzory ${ }^{4}$. W wyroku tego Sądu z roku 2007 podkreślono, iż wytwór graficzny, aby mógł zostać uznany za wzór przemysłowy, powinien być na tyle precyzyjny, aby można go było odtworzyć.

Zgodnie z art. 102 ust. 1 p.w.p. rejestracji podlega postać wytworu, nadana mu w szczególności przez cechy linii, konturów, kształtów i kolorystykę. W pierwszej kolejności należy zbadać zatem, czy istnieje w ogóle postać wytworu, a dopiero potem można badać jej nowość i indywidualność ${ }^{5}$.

W ustawie, a dokładnie w art. 104 ust. 1 tego aktu normatywnego, zamieszczono definicję przesłanki indywidualnego charakteru. Otóż zgodnie z tym przepisem wzór przemysłowy odznacza się indywidualnym charakterem, jeżeli ogólne wrażenie, jakie wywołuje na zorientowanym użytkowniku, różni się od ogólnego wrażenia wywołanego na nim przez wzór publicznie udostępniony przed data, według której oznacza się

4 Wyrok WSA w Warszawie z dnia 29 marca 2007 r. sygn. akt VI SA/Wa 1716/2006, opublik. w „LexPolonica” nr 1999721 ONSAiWSA 2009/1, poz. 13.

5 Wyrok WSA w Warszawie z roku 2007 VI SA/Wa 2128/2007, opublik. w „LexPolonica” nr 1833528, „Gazeta Prawna” 2008/38, s. 10. 
pierwszeństwo. Przy ocenie indywidualnego charakteru wzoru przemysłowego należy brać pod uwagę zakres swobody twórczej przy opracowywaniu wzoru 6 .

Ochrona wzorów przemysłowych odbywa się w oparciu o tzw. prawa $\mathrm{z}$ rejestracji. Przez uzyskanie prawa z rejestracji uprawniony nabywa prawo wyłącznego korzystania z wzoru przemysłowego w sposób zarobkowy lub zawodowy na całym obszarze Rzeczypospolitej Polskiej. Oznacza to, iż podmiot uprawniony może zakazać osobom trzecim wytwarzania, oferowania, wprowadzania do obrotu, importu, eksportu lub używania wytworu, w którym wzór jest zawarty bądź zastosowany, lub składowania takiego wytworu dla takich celów. Należy jednak podkreślić, iż prawo $\mathrm{z}$ rejestracji wzoru przemysłowego ogranicza się do wytworów tego rodzaju, dla których nastąpiło zgłoszenie ${ }^{7}$. Zgodnie art. 105 ust. 6 prawa

${ }^{6}$ Warto tu odnotować pogląd sformułowany w wyroku Sądu Najwyższego - Izba Cywilna z dnia 23 października 2007 r. (sygn. akt II CSK 302/2007) opublik. „LexPolonica” nr 1855385 „Biuletyn Sądu Najwyższego” 2008/2 OSNC 2008/B, poz. 52; OSP 2009/6 poz. 66; ,Zeszyty Naukowe Sądownictwa Administracyjnego” 2008/4, s. 94. patrz także glosa aprobująca M. Poźniak-Niedzielska opublik. w OSP 2009/6, s. 455. Teza ta brzmi następująco: „Badanie, na podstawie art. 105 ust. 4 w zw. $z$ ust. 1 ustawy z dnia 30 czerwca 2000 r. Prawo własności przemysłowej czy doszło do naruszenia prawa $\mathrm{z}$ rejestracji wzoru przemysłowego, wymaga całościowego porównania wzorów z punktu widzenia osoby używającej w sposób stały przedmiotów z danej grupy i zorientowanej w stanie ich wzornictwa wynikającym z zakresu swobody twórczej oraz dokonanie oceny, czy ogólne wrażenie, jakie wywołuje na takiej osobie wzór zakwestionowany różni się od ogólnego wrażenia wywołanego przez wzór zarejestrowany".

${ }^{7}$ Ustawodawca przewidzial jednak pewne ograniczenia w tym zakresie. Otóż praw z rejestracji nie udziela się na wzory przemysłowe, których wykorzystywanie byłoby sprzeczne z porządkiem publicznym lub dobrymi obyczajami; korzystania $\mathrm{z}$ wzoru przemysłowego nie uważa się za sprzeczne z porządkiem publicznym tylko dlatego, że jest zabronione przez prawo. Praw z rejestracji nie udziela się również, na wzory przemysłowe zawierające oznaczenia, zawierające nazwę lub skrót nazwy Rzeczypospolitej Polskiej bądź jej symbole (godło, barwy lub hymn), nazwy lub herby polskich województw, miast lub miejscowości, znaki sił zbrojnych, organizacji paramilitarnych lub sił porządkowych, reprodukcje polskich orderów, odznaczeń lub odznak honorowych, odznak lub oznak wojskowych bądź innych oficjalnych lub powszechnie używanych odznaczeń i odznak, w szczególności administracji rządowej czy samorządu terytorialnego albo organizacji społecznych działających w ważnym interesie publicznym, gdy obszar działania tych organizacji obejmuje cały kraj lub znaczną jego część, jeżeli zgłaszający nie wykaże się uprawnieniem, w szczególności zezwoleniem właściwego organu Państwa albo zgodą organizacji, na używanie oznaczenia w obrocie; zawierają skróty nazw bądź symbole (herby, flagi, godła) obcych państw, organizacji międzynarodowych, a także przyjęte w obcych państwach urzędowe ozna- 
z rejestracji wzoru udziela się na 25 lat od daty dokonania zgłoszenia w Urzędzie Patentowym, podzielone na pięcioletnie okresy ${ }^{6}$. Warto tu także wyjaśnić, iż prawo z rejestracji wzoru przemysłowego nie obejmuje cech wytworu: 1) wynikających wyłącznie z jego funkcji technicznej, 2) które muszą być odtworzone w dokładnej formie i wymiarach w celu umożliwienia mechanicznego połączenia go lub współdziałania z innym wytworem ${ }^{7}$.

Udzielone prawa z rejestracji wzorów przemysłowych podlegają wpisowi do rejestru wzorów przemysłowych, co potwierdza się wydaniem świadectwa rejestracji. Częścią składową świadectwa rejestracji jest opis ochronny wzoru przemysłowego obejmujący opis tego wzoru, rysunek oraz zawarte w zgłoszeniu fotografie i ewentualnie próbki materiału włókienniczego.

Uprawniony z rejestracji wzoru przemysłowego nie może jednak zakazać osobie trzeciej korzystania z wzoru: 1) do użytku osobistego lub niezwiązanego z działalnością gospodarczą, 2) w celu doświadczalnym,

czenia, stemple kontrolne i gwarancyjne, jeżeli zakaz taki wynika z umów międzynarodowych, chyba że zgłaszający wykaże się zezwoleniem właściwego organu, które uprawnia go do używania takich oznaczeń w obrocie; zawierają urzędowo uznane oznaczenia przyjęte do stosowania w obrocie, w szczególności znaki bezpieczeństwa, znaki jakości lub cechy legalizacji, w zakresie, w jakim mogłoby to wprowadzić odbiorców w błąd co do charakteru takich oznaczeń, o ile zgłaszający nie wykaże, że jest uprawniony do ich używania; zawierają elementy będące symbolami, w szczególności o charakterze religijnym, patriotycznym lub kulturowym, których używanie obrażałoby uczucia religijne, patriotyczne lub tradycję narodową.

${ }^{6}$ Zgodnie $\mathrm{z}$ art. 111 ust. 1 ustawy Urząd Patentowy wydaje decyzję o udzieleniu prawa $\mathrm{z}$ rejestracji po stwierdzeniu, że zgłoszenie wzoru przemysłowego zostało sporządzone prawidłowo. Udzielenie prawa z rejestracji wzoru przemysłowego następuje pod warunkiem uiszczenia opłaty za pierwszy okres ochrony. W razie nieuiszczenia opłaty w wyznaczonym terminie Urząd Patentowy stwierdza wygaśnięcie decyzji o udzieleniu prawa $\mathrm{z}$ rejestracji wzoru przemysłowego. Zgodnie $\mathrm{z}$ art. $106^{1}$ ust. 1 ustawy ochrona z tytułu prawa z rejestracji wzoru nie przysługuje wytworowi, który stanowi część składową wytworu złożonego, używaną do naprawy tego wytworu w taki sposób, by przywrócić mu jego wygląd początkowy. Osoby trzecie mogą korzystać z takiego wytworu, poprzez jego wytwarzanie, oferowanie, wprowadzanie do obrotu, import, eksport lub używanie wytworu, w którym wzór jest zawarty bądź zastosowany, lub poprzez składowanie takiego wytworu dla takich celów.

7 Tak art. 107 ust. 1 ustawy. Przepisy przywołanego powyżej ust. 1 nie stoją na przeszkodzie rejestracji wzoru przemysłowego przeznaczonego do wielokrotnego składania lub łączenia wzajemnie wymienialnych wytworów w ramach systemu modularnego. 
3) polegającego na jego odtworzeniu do celów cytowania lub nauczania, jeżeli nie narusza dobrych obyczajów i nie utrudnia uprawnionemu w sposób nieuzasadniony korzystania z wzoru oraz wskazuje na źródło jego pochodzenia, 4) stosowanego lub zawartego w urządzeniach znajdujących się na środkach transportu lądowego i zarejestrowanych w innych państwach statkach morskich lub powietrznych, które czasowo znajdują się na obszarze Rzeczypospolitej Polskiej, 5) przez import części zamiennych i akcesoriów, w których wzór jest stosowany lub zawarty w celu napraw takich statków, wykonywania ich napraw lub przez wykonanie na indywidualne zamówienie naprawy związanej z odtworzeniem części składowej wytworu złożonego, w celu przywrócenia mu pierwotnego wyglądu.

$\mathrm{Z}$ kolei zgodnie $\mathrm{z}$ treścią art. 118 ust. 1 tego aktu normatywnego, do wzorów przemysłowych i praw z rejestracji wzorów przemysłowych stosuje się odpowiednio, m.in. art. 76-79 tej ustawy, tzn. przepisy dotyczące licencji. Choć ustawa nie definiuje tego pojęcia, to w doktrynie przyjmuje się, iż termin licencja „oznacza zezwolenie (upoważnienie) podmiotu uprawnionego, udzielone innej osobie zwane licencjobiorca, do dokonywania czynności prawnych lub faktycznych, przysługujących w zasadzie wyłącznie licencjodawcy. Na skutek udzielenia licencji adresat upoważnienia nabywa uprawnienie do korzystania z określonego dobra [... $]^{\prime 10}$. Skoro tak to przypomnieć należy, że zgodnie z art. 105 ust. 2 ustawy przez uzyskanie prawa z rejestracji uprawniony nabywa prawo wyłącznego korzystania z wzoru przemysłowego w sposób zarobkowy lub zawodowy na całym obszarze Rzeczypospolitej Polskiej. Oznacza to, iż uprawniony może zakazać osobom trzecim wytwarzania, oferowania, wprowadzania do obrotu, importu, eksportu lub używania wytworu, w którym wzór jest zawarty bądź zastosowany, lub składowania takiego wytworu dla takich celów ${ }^{11}$.

10 Tak S. Sołtysiński, w: System prawa własności intelektualnej, t. III: Prawo wynalazcze, red. J. Szwaja, A. Szajkowski, Wrocław-Warszawa-Kraków-Gdańsk-Łódź 1990, s. 458; M. du Vall, Prawo patentowe, Warszawa 2008, s. 279. Na marginesie należy odnotować, iż zgodnie art. 76 ust. 1 umowa licencyjna wymaga, pod rygorem nieważności, zachowania formy pisemnej.

11 Inne obowiązki określono w art. 77 ustawy, a mianowicie jeżeli umowa licencyjna nie stanowi inaczej, licencjodawca jest obowiązany do przekazania licencjobiorcy wszystkich posiadanych przez niego w chwili zawarcia umowy licencyjnej informacji i doświadczeń technicznych potrzebnych do korzystania z wynalazku. Pamiętać także należy, iż w razie przejścia patentu obciążonego licencją, umowa licencyjna jest skuteczna wobec następcy prawnego. 
Należy tu odnotować, że w art. 76 ust. 4 ustawy zdefiniowano pojęcie licencji niewyłącznej. Mianowicie zgodnie z tym przepisem ,jeżeli umowa licencyjna nie zastrzega wyłączności korzystania z wynalazku w określony sposób, udzielenie licencji jednej osobie nie wyklucza możliwości udzielenia licencji innym osobom, a także jednoczesnego korzystania z wynalazku przez uprawnionego z patentu", ${ }^{\prime 2}$. Z kolei w art. 76 ust. 2 przywoływanego aktu normatywnego, zdefiniowano pojęcie licencji pełnej i ograniczonej. Ten pierwszy rodzaj (zwany także licencją prostą lub negatywną) oznacza możliwość korzystania ,z wynalazku w takim samym zakresie jak licencjodawca"13. Zgodzić należy się z także poglądem, iż ,[...] ustawodawca wprowadza tu także regułę interpretacyjną, nakazującą taktować licencję jako pełną, chyba że ograniczenie korzystania z wynalazku wynika wyraźnie z treści umowy. [...] Ustanowienie licencji pełnej oznacza więc, że uprawnionemu służy cała triada możliwości eksploatowania wynalazku" "14.

Zdaniem S. Sołtysińskiego ,umowa licencyjna, zawierająca wyraźnie udzielenie upoważnienia do stosowania wynalazku, daje uprawnionemu możliwość używania wyprodukowanych wyrobów i wprowadzania ich do obrotu" "15. Zgodzić się także należy, że ,wszelkie ograniczenia zakresu korzystania z wynalazku oznaczają, że licencja jest ograniczona. Granicę ograniczeń stanowią jednak przepisy prawa antymonopolowego, z których wynikają zakazy wprowadzania do umowy klauzul stanowiących niedozwoloną praktykę w rozumieniu art. 5 ustawy o ochronie konkurencji i konsumentów"16.

Podzielić należy także pogląd, iż „zawarcie ważnej umowy licencyjnej powoduje natychmiast, a nie dopiero w przyszłości powstanie po stronie licencjobiorcy upoważnienia do korzystania z wynalazku, licencjodawca zaś jest odtąd związany dokonaną czynnością, umowa licencyjna wywołuje nadto skutki zobowiązujące, wynikające z treści umowy lub usta-

12 Patrz także M. du Vall, Prawo własności przemysłowej. Wynalazki, wzory użytkowe, projekty racjonalizatorskie, t. I, Zakamycze 2005, s. 89; tenże, Prawo patentowe, op. cit., s. 282.

13 Tak art. 76 ust. 2 zd. 2 ustawy; patrz także S. Sołtysiński, w: System, op. cit., s. 462; M. du Vall, Prawo własności przemysłowej, op. cit., s. 89; tenże, Prawo patentowe, Warszawa 2008, s. 282.

14 S. Sołtysiński, System, op. cit., s. 462; na mocy art. 118 ust. 1 ustawy należy ten - jak i wszystkie inne tu przytaczane - pogląd odpowiednio odnosić do wzorów przemysłowych - przyp. JS.

15 Ibidem, s. 464.

16 M. du Val, Prawo własności przemysłowej, op. cit., s. 89. 
wy"17. Natomiast w kwestii praw i obowiązków stron, a w szczególności licencjobiorcy, odnotować należy stanowisko prezentowane w doktrynie, iż „ustawa nie nakłada na licencjobiorcę w sposób wyraźny żadnego obowiązku. Należy więc najpierw ustalić, czy w oparciu o klauzule generalne lub inne normy k.c., stosowane choćby w drodze analogii, można mu przypisać jakiś konkretny obowiązek poza zobowiązaniem do przestrzegania postanowień umowy, wyznaczających granice udzielonego mu upoważnienia. Do obowiązków licencjobiorcy zalicza się ponadto zobowiązania: 1) zapłaty wynagrodzenia pieniężnego, 2) stosowania wynalazku, 3) niepodważania ważności patentu oraz 4) informowania licencjodawcy o faktach naruszania prawa wyłączności przez osoby trzecie. Żaden z wymienionych czterech obowiązków nie może być uznany za na tyle charakterystyczny składnik czynności prawnej, jak obowiązek znoszenia aktów korzystania z wynalazku po stronie licencjodawcy, który aczkolwiek nie sprecyzowany wyraźnie przez ustawodawcę, lecz ustalony w drodze wykładni, nie może zostać wyłączony wolą stron, gdyż sprzeciwiałoby się to celowi gospodarczemu kontraktu i zasadom współżycia społecznego"18. Zgodzić należy się także, że „umowa licencyjna stanowi szczególną, pozakodeksową umowę nazwaną. Do spraw nieuregulowanych przepisami p.w.p. mają zatem zastosowanie przepisy księgi I k.c. pt. „Cześć ogólna”

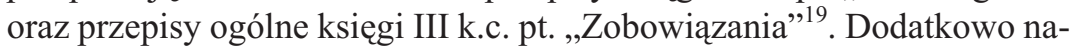
leży podkreślić, że w doktrynie wskazuje się, że licencjobiorca zobowiązany jest „do korzystania ze swojego prawa, jeśli przemawiają za tym treść umowy, zasady współżycia społecznego lub ustalone zwyczaje $\mathrm{e}^{20}$.

Odnaleźć można także pogląd, iż ,[...] na wezwanie licencjodawcy uprawniony winien złożyć oświadczenie, czy i w jakim zakresie stosuje wynalazek lub wprowadza do obrotu towary wykorzystujące ów projekt [...]. Jednakże obowiązek informowania o zakresie stosowania (np. przy wprowadzeniu zależnym od wielkości produkcji licencyjnej) nie implikuje automatycznie obowiązku poddania kontroli licencjodawcy ksiąg handlowych lub zakładów produkcyjnych licencjobiorcy"21.

17 S. Sołtysiński, System, op. cit., s. 464.

18 Ibidem, s. 475; patrz także M. du Vall, Prawo patentowe, op. cit., s. 280 oraz M. Załucki, Licencja na używanie znaku towarowego. Studium prawnoporównawcze, Warszawa 2008, s. 236 i n.

19 M. du Vall, Prawo patentowe, op. cit., s. 281.

20 Tak art. 56 k.c. - S. Sołtysiński, System, op. cit., s. 476.

21 Ibidem, s. 477. 
Odnotować trzeba także stanowisko prezentowane w literaturze przedmiotu, iż ,[...] umowa licencyjna wymaga na ogół szczególnego zaufania i współpracy stron. $Z$ tego względu w braku odmiennego porozumienia stron zazwyczaj przyjmuje się, że obowiązki wynikające z umowy mogą być wykonywane tylko przez podmioty, które ją zawarły. Przeniesieniu praw i obowiązków sprzeciwia się w tych wypadkach właściwość zobowiązania. Wiele typowych obowiązków występujących na tle umowy licencyjnej ma charakter świadczeń osobistych w tym znaczeniu, że ich wartość i gwarancje spełnienia zależą od pozycji finansowej i umiejętności technicznych stron. Podobne względy przesądzają o domniemaniu nieprzenoszalności w drodze czynności prawnej praw i obowiązków licencjata. Jedynie w wypadkach sukcesji pod tytułem ogólnym (spadkobranie), łączenia przedsiębiorstw, nabycia przedsiębiorstwa przez osobę trzecią i bankructwa jednej ze stron można bronić tezy o dopuszczalności przejścia praw i obowiązków licencyjnych ${ }^{22}$.

Trzeba także przypomnieć, że z kolei art. w 76 ust. 5 stanowi się, iż „uprawniony z licencji może udzielić dalszej licencji (sublicencja) tylko za zgodą uprawnionego z patentu. W doktrynie traktuje się sublicencję jako obciążenie prawa licencjobiorcy (czynność rozporządzająco-zobowiązująca), która dzieli los licencji ${ }^{23}$. Zgodzić należy się ze stanowiskiem prezentowanym w doktrynie, iż ,skoro umowa licencyjna wymaga, pod rygorem nieważności formy pisemnej (art. 76 ust. 1 ustawy) to zgoda ta musi być wyrażona również na piśmie. W umowie sublicencyjnej zmienia się rola licencjobiorcy. Mianowicie w stosunku do sublicencjobiorcy jest on sublicencjodawcą ${ }^{24}$.

Warto tu przyjrzeć się także regulacjom zawartym w dyrektywie 98/71/WE Parlamentu Europejskiego i Rady z dnia 13 października 1998 r. w sprawie prawnej ochrony wzorów ${ }^{25}$. Otóż zgodnie z art. 12 dyrektywy, dotyczącego zakresu uprawnień wynikających z rejestracji wzoru, stanowi się, że rejestracja wzoru przyznaje jego posiadaczowi wyłączne prawo użytkowania i chroni przed użytkowaniem przez strony trzecie, które nie

22 Ibidem.

23 S. Sołtysiński, System, op. cit., s. 492.

24 Tak M. du Vall, Prawo własności przemysłowej, op. cit.; tenże, Prawo patentowe, s. 284-285; E. Nowińska, Prawo własności przemysłowej. Wzory przemysłowe, znaki towarowe, oznaczenia geograficzne, t. II, Zakamycze 2005.

25 Dz. U. UE L z dnia 28 października 1998 r., Dz. U. UE L 1998.289.28; Dz. U. UE-sp.13-21-120. 
mają jego zgody. Wymienione wcześniej użytkowanie obejmuje w szczególności wytwarzanie, oferowanie, wprowadzanie na rynek, przywóz, wywóz lub używanie produktu, do którego włączono lub do którego odnosi się wzór, lub magazynowanie takiego produktu w tych celach. W tym kontekście warto przytoczyć tezę zawartą w wyroku z dnia 20 marca 2007 r. Naczelnego Sądu Administracyjnego ${ }^{26}$, mianowicie ochrona wzoru przemysłowego dotyczy celów gospodarczych obejmując, jak to wynika $\mathrm{z}$ art. 105 ust. 3 p.w.p., wytwarzanie, oferowanie, wprowadzanie do obrotu, import, eksport, używanie wytworu, w którym wzór jest zawarty bądź zastosowany oraz jego składowanie dla takich celów. Decyduje zatem wszystko to, co dzieje się na rynku, dopóki wytwór, do którego odnosi się wzór, znajduje się lub może znajdować się w tak rozumianym obrocie rynkowym.

Podobnie tę kwestię normuje rozporządzenie Rady (WE) NR 6/2002 $\mathrm{z}$ dnia 12 grudnia $2001 \mathrm{r}$. w sprawie wzorów wspólnotowych ${ }^{27}$. W myśl art. 19 tego aktu normatywnego „Zarejestrowany wzór wspólnotowy przyznaje jego właścicielowi wyłączne prawo do jego używania i zakazywania osobom trzecim jego używania, które nie mają jego zgody. Wyżej wymienione używanie obejmuje, w szczególności, wytwarzanie, oferowanie, wprowadzanie do obrotu, import, eksport lub używanie produktu, w którym wzór jest zawarty bądź zastosowany lub składowanie takiego produktu w tych celach". W art. 32 rozporządzenia rozstrzygnięto, iż wzór wspólnotowy może być przedmiotem licencji (wyłącznej lub niewyłącznej) na terenie całej Wspólnoty lub jej części. W ust. 2 tego przepisu stanowi się, iż bez uszczerbku dla ewentualnych roszczeń wynikających z umowy właściciel może powoływać się na prawa uzyskane ze wzoru wspólnotowego przeciwko licencjobiorcy, który narusza jakiekolwiek postanowienie umowy licencyjnej w odniesieniu do czasu jej obowiązywania, formy, w jakiej wzór może być używany, asortymentu produktów, na które licencja została udzielona i jakości produktów produkowanych przez licencjobiorcę. Z kolei w ust. 5 tego przepisu stanowi się, iż w przypadku zarejestrowanego wzoru wspólnotowego udzielenie lub przeniesienie licencji dotyczącej takiego prawa, na wniosek jednej ze stron, wpisuje się do rejestru i publikuje.

26 Wyrok z dnia 20 marca 2007 r. Naczelnego Sądu Administracyjnego (sygn. akt II GSK 277/06, opublik. „LEX” nr 321283321283).

27 Dz. U. UE L z dnia 5 stycznia 2002 r. 
Konkludując należy stwierdzić, iż uzyskując licencję niewyłaczną oraz pełną, otrzymuje się zezwolenie podmiotu uprawnionego, udzielone licencjobiorcy, do dokonywania czynności prawnych lub faktycznych, przysługujących licencjodawcy. Z faktu, iż licencja jest pełną wynika możliwość korzystania z wzoru przemysłowego w takim samym zakresie jak licencjodawca. Jak już wyżej podkreślono, pamiętać należy, że jednym z obowiązków licencjobiorcy jest stosowanie wzoru przemysłowego.

Pojawić się jednak może problem, gdy okaże się, że z jakichkolwiek powodów (np. zmian organizacyjnych w ramach grupy kapitałowej), iż licencjobiorca nie dysponuje możliwościami technicznymi, organizacyjnymi, aby takie zadanie wykonać. Stąd konieczność zlecenia wykonania czynności wyłącznie technicznych innemu podmiotowi. Rodzi się jednak pytanie czy złożenie takiego zlecenia - w świetle powyższych uwag - nie będzie naruszać warunków licencji? Kwestia ta nie została do tej pory wyjaśniona przez judykaturę, a w doktrynie także brak jednoznacznej odpowiedzi na takie wątpliwości.

Wydaje się jednak, że jeżeli organizacja procesu produkcyjnego oraz wyłączne decydowanie o zasadach, warunkach oraz skali produkcji przysługiwać będzie w dalszym ciągu licencjobiorcy z prawem własności wytworzonego produktu przez ten podmiot, $\mathrm{z}$ faktem wprowadzania produktu pod własną marką licencjobiorcy, oraz faktycznego decydowania o zasadach wprowadzania na rynek produktu, w tym z pełną, suwerenna i nieograniczoną swobodą w ustalaniu warunków handlowych w postaci ceny, marży oraz terminu płatności, oraz z ponoszeniem pełnej odpowiedzialności za jakość wprowadzonego na rynek towaru, natomiast rola zleceniobiorcy sprowadzać się będzie jedynie do wykonania czynności wyłącznie technicznych związanych z wyprodukowaniem przedmiotu chronionego wzorem przemysłowym, to w takim przypadku działanie licencjobiorcy będzie mieścić się $\mathrm{w}$ granicach udzielonej licencji.

Oczywiście najprostszym rozwiązaniem byłoby zaproponowanie udzielenia sublicencji. Przypomnijmy jednak, iż sublicencję definiuje się jako obciążenie prawa licencjobiorcy (czynność rozporządzająco-zobowiązująca), która dzieli los licencjii ${ }^{28}$. Jest to z pewnością czynność prawna o szerszym zakresie niż tu rozważana sytuacja. Niekiedy zreszta, $z$ uwagi na postanowienia licencyjne, udzielenie takiej sublicencji jest niemożliwe. 
Wydaje się także, że wyżej prezentowanemu stanowisku nie przeczy prezentowany powyżej pogląd, iż ,[...] umowa licencyjna wymaga na ogół szczególnego zaufania i współpracy stron. Z tego względu w braku odmiennego porozumienia stron zazwyczaj przyjmuje się, że obowiązki wynikające z umowy mogą być wykonywane tylko przez podmioty, które ją zawarły. Przeniesieniu praw i obowiązków sprzeciwia się w tych wypadkach właściwość zobowiązania. Wiele typowych obowiązków występujących na tle umowy licencyjnej ma charakter świadczeń osobistych w tym znaczeniu, że ich wartość i gwarancje spełnienia zależą od pozycji finansowej i umiejętności technicznych stron. Podobne względy przesądzają o domniemaniu nieprzenoszalności w drodze czynności prawnej praw i obowiązków licencjata"29. Wydaje się, że właściwość zobowiązania nie sprzeciwia się zleceniu jedynie wyprodukowania określonej partii towaru innemu podmiotowi. Wszystkie istotne z punktu widzenia licencjodawcy kwestie związane z istotą takiego zobowiązania, a więc organizacja procesu produkcyjnego, decydowanie o zasadach, warunkach oraz skali produkcji, prawo własności wytworzonego produktu, wprowadzanie produktu pod własną marką oraz faktycznego decydowania o zasadach wprowadzania na rynek produktu, w tym z pełną, suwerenną i nieograniczoną swobodą w ustalaniu warunków handlowych w postaci ceny, marży oraz terminu płatności, oraz co nie mniej ważne z ponoszeniem pełnej odpowiedzialności za jakość wprowadzonego na rynek towaru, pozostana po stronie licencjobiorcy. Podmiot zajmujący się produkcją sprowadzony zostaje jedynie do udostępnienia mocy produkcyjnych przystosowanych do tego typu działalności wytwórczej i udostępnieniu siły roboczej.

W tym kontekście rozważyć należy dodatkowo treść art. 105 ust. 3 prawa własności przemysłowej (ale także przytaczanych regulacji prawa Unii Europejskiej), który przyznaje uprawnionemu z prawa z rejestracji możliwość zakazania osobom trzecim wytwarzania, oferowania, wprowadzania do obrotu, importu, eksportu lub używania wytworu, w którym wzór jest zawarty bądź zastosowany, lub składowania takiego wytworu dla takich celów. Pojawia się tu zatem niezaprzeczalnie możliwość zakazania wytwarzania chronionego wytworu, w którym wzór jest zawarty. Wydaje się jednak, że przypadek, gdy wytwarzanie przez inny podmiot odbywa się na rzecz i rachunek podmiotu uprawnionego z licencji, nie stoi w sprzeczności z powyższym uprawnieniem.

29 S. Sołtysiński, op. cit., s. 492. 


\section{Summary}

The paper analyzes the rights and responsibilities of the parties of license agreements concerning industrial providd for in Polish and EU regulations. In particular, it attempts to answer the question whether the licensee's commissioning of manufacturing activities may infringe on the license conditions. It is proposed here that such licensee conduct is covered by the extent of the license provided that the licensee is in charge of organizing the manufacturing process and solely decides about the principles, conditions and the scale of production; he retains the ownership right to the product manufactured; the product is introduced under the licensee's own brand; the licensee actually decides about the principles under which the product is launched on the market, including the complete, independent and unlimited freedom of deciding about the commercial conditions concerning the price, markup and term of payment; and the licensee bears full responsibility for the quality of the commodity entered into the market whereas the role of the contractor is limited to the performance of technical activities related to the manufacturing of the product protected by the indial. 